\title{
PENGARUH PENERAPAN METODE STAD DENGAN MENGGUNAKAN LABORATORIUM VIRTUAL TERHADAP HASIL BELAJAR KIMIA SISWA
}

\author{
Vivi Rayanti ${ }^{1)}$, Elvi Yenti ${ }^{2)}$ \\ ${ }^{1}$ Pendidikan Kimia, Fakultas Tarbiyah dan Keguruan, UIN Suska Riau \\ Email viivirayantii24@gmail.com \\ ${ }^{2}$ Pendidikan Kimia, Fakultas Tarbiyah dan Keguruan, UIN Suska Riau \\ Email elviyenti10@gmail.com
}

\begin{abstract}
This research is prompted by students' low learning outcomes. One of the ways that can be performed to increase students' learning outcomes is Student Teams Achievement Division (STAD) learning method by using virtual laboratory. This research is aimed at looking at the effect of STAD learning method by using virtual laboratory toward students' learning outcomes in Redox Reaction material of grade 10 students at State Senior High School 1 Mandau. This research is a quasi-experiment research by using Pretest-Posttest Control Group Design with two sample classes: Class X 3 as experiment research and Class $X 4$ as control class. In this research, the meeting was conducted for four times. The techniques of collecting the data in this research are Homogeneity test as initial data, Pretest and Posttest as final data, Interview, and Documentation. Initial and final data are analyzed by using t-test. This research shows that there are some differences on students' learning outcomes between experiment class and control class. Final data analysis generates the value of $t_{\text {counting }}=2.8904$ and $t_{\text {table }}=$ 1.9983 that shows $t_{\text {counting }}>t_{\text {table. }}$. As $H_{o}$ is rejected, it can be concluded that there is an effect of applying STAD learning method by using virtual laboratory toward students' learning outcomes which is as much as $11.70 \%$.
\end{abstract}

Keywords: STAD, virtual laboratory, redox reaction

\section{PENDAHULUAN}

Pendidikan merupakan salah satu wadah bagi seseorang untuk mendapatkan pengetahuan. Al-Qur'an telah berulang kali menjelaskan akan pentingnya pengetahuan. Tanpa pengetahuan niscaya kehidupan manusia akan menjadi sengsara. Allah swt telah memperingatkan manusia agar mencari ilmu pengetahuan, sebagaimana dalam al-Qur'an surat atTaubah ayat 122 disebutkan :
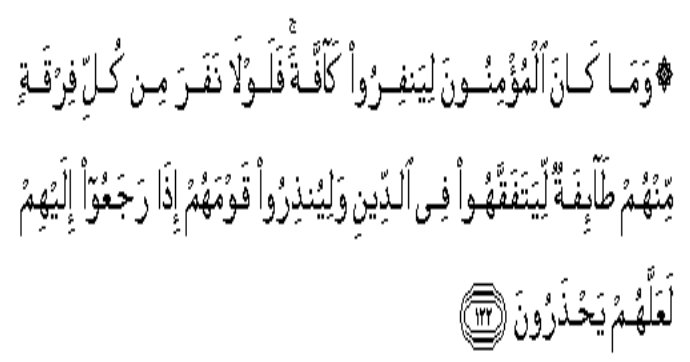

Artinya :"Tidak sepatutnya bagi orang-orang yang mukmin itu pergi semuanya (ke medan perang). Mengapa tidak pergi dari tiap-tiap golongan diantara mereka beberapa orang untuk memperdalam pengetahuan mereka tentang agama dan untuk memberi peringatan kepada kaumnya apabila mereka telah kembali kepadanya, supaya mereka itu dapat menjaga dirinya". (Q.S at-Taubah : 122)

Pada ayat tersebut mengandung keterangan tentang keutamaan ilmu dan pentingnya ilmu pengetahuan, yakni siapa yang mempelajari ilmu, maka dia harus menyebarkannya dan mengajarkannya serta memberikan nasehat kepada orang lain, karena menyebarkan ilmu adalah termasuk keberkahan yang pahalanya berkembang [1].

Keutamaan dan pentingnya ilmu pengetahuan dapat dimiliki oleh seseorang melalui pendidikan. Pendidikan memegang peranan penting dalam menciptakan 
masyarakat yang cerdas baik secara intelektual, emosional, maupun spiritual [2]. Untuk mencapai tujuan tersebut, pemerintah melakukan berbagai upaya untuk meningkatkan kualitas pendidikan, antara lain melalui pergantian kurikulum, meningkatkan sarana prasarana sekolah, meningkatkan kualitas pendidik dengan banyak diadakannya pelatihan, memfasilitasi masyarakat yang kurang mampu untuk sekolah melalui beasiswa, dan program lainnya [3]. Banyak upaya yang dilakukan pemerintah dan masyarakat untuk memajukan pendidikan di Indonesia, namun pada dasarnya semua berporos pada pembaharuan kurikulum pendidikan [4].

$\begin{array}{crrr}\text { Kurikulum } & \text { Tingkat } & \text { Satuan } \\ \text { Pendidikan (KTSP) } & \text { yang } & \text { sedang }\end{array}$ diterapkan oleh pemerintah, memiliki tujuan untuk memandirikan dan memberdayakan satuan pendidikan melalui pemberian kewenangan (otonomi) kepada lembaga pendidikan yang akan mendorong sekolah untuk melakukan pengambilan keputusan secara partisipatif dalam pengembangan kurikulum [5]. KTSP juga memiliki karakter yang khas yakni mengacu pada pembelajaran yang berpusat pada siswa [6]. Siswa berperan aktif dalam mengkonstruksi pengetahuannya, dengan demikian pembelajaran tidak hanya sekedar hafalan dan pemahaman. Untuk mengoptimalkan peran siswa dalam pembelajaran dikembangkan strategi, metode, dan media pembelajaran yang mengacu pada student centered learning [7].

Dalam proses pembelajaran di bidang sains khususnya kimia, proses pembelajaran yang berhasil memerlukan teknik, metode, dan pendekatan tertentu yang sesuai dengan karakteristik tujuan pendidik, materi, dan sumber daya [8]. Kreatifitas guru dan keaktifan merupakan aspek yang penting agar proses pembelajaran dapat terlaksana dengan baik dan tujuan pembelajaran juga dapat tercapai [9]. Hal ini dikarenakan topik kimia pada umumnya berkaitan dengan struktur zat dan adanya konsep-konsep yang terkandung dalam ilmu kimia yang kompleks, sehingga kimia dianggap sebagai pelajaran sulit bagi banyak siswa [10]. Menurut Nurhayati, mata pelajaran Kimia selain disampaikan dalam bentuk teori juga harus didukung oleh kegiatan praktikum di laboratorium, supaya materi pelajaran yang disampaikan lebih dipahami dan lebih ada gambaran untuk hal-hal yang abstrak dalam materi pelajaran Kimia [11]. Laboratorium merupakan bagian dari sarana prasarana yang harus dimiliki sekolah.

Sarana prasarana sekolah memang telah mendapatkan perhatian yang tinggi dari pemerintah. Tetapi, perhatian itu hanya berbentuk sloganisme, secara faktual fasilitas dan sarana Pendidikan memburuk [12]. Usaha pemerintah ini masih butuh waktu karena tidak semua sekolah memiliki sarana prasarana yang memadai. Hal ini sesuai dengan hasil angket yang telah diberikan pada siswa SMA N 1 Mandau bahwa laboratorium yang dimiliki sekolah tersebut tidak lengkap, sehingga siswa tidak terlalu sering melakukan praktikum. Padahal untuk mata pelajaran Kimia, sangat dibutuhkan adanya laboratorium.

Kondisi pembelajaran kimia pada saat ini berdasarkan informasi yang diterima pada salah satu SMA, yakni SMA N 1 Mandau melalui Bapak Aroni Diyanto, S.Pd pada 04 April 2015 diperoleh bahwa hasil belajar kimia siswa masih rendah, yakni sebanyak $60 \%$ nilai siswa dibawah standar Kriteria Ketuntasan Minimum (KKM). Pada sekolah ini KKM yang ditetapkan pada mata pelajaran Kimia khususnya untuk kelas X adalah 80. Dalam proses pembelajaran juga diperoleh informasi bahwa masih ada siswa yang belum mengerti materi pelajaran kimia, dan masih ada siswa yang ragu dalam menjawab pertanyaan dari guru. Fasilitas laboratorium tidak memadai untuk melakukan banyak praktikum, karena alat yang dimiliki masih terbatas. Selain itu, berdasarkan hasil angket yang telah disebarkan pada sekolah tersebut diperoleh bahwa guru belum pernah menggunakan laboratorium virtual dan penggunaan media pembelajaran lainnya. 
Untuk membuat siswa aktif dalam proses pembelajaran dan mendapatkan hasil belajar yang baik, serta meningkatkan pemahaman siswa mengenai materi kimia, maka harus diterapkan salah satu metode yakni Student Teams Achievement Division (STAD). Metode pembelajaran STAD merupakan salah satu strategi pembelajaran kooperatif yang didalamnya beberapa kelompok kecil siswa dengan level kemampuan akademik yang berbedabeda saling bekerja sama untuk menyelesaikan tujuan pembelajaran [13]. Penggunaan metode ini didukung dengan media pembelajaran yang memanfaatkan sarana dan prasarana yang dimiliki sekolah.

Perkembangan Ilmu Pengetahuan dan Teknologi (IPTEK) sangat membantu permasalahan sarana prasarana sekolah yang belum memadai. Aplikasi komputer dalam bentuk laboratorium virtual merupakan hasil perkembangan IPTEK yang dapat dijadikan salah satu solusi dalam mengatasi permasalahan tersebut dan dapat dijadikan sebagai media pembelajaran tambahan untuk meningkatkan hasil belajar siswa. Laboratorium virtual ini dapat membuat siswa dapat melakukan praktikum kimia yang penting untuk pemahamannya tanpa harus memiliki sebuah laboratorium asli. Adanya aplikasi ini, disisi lain juga akan mengurangi produksi limbah kimia yang digunakan dalam praktikum. Hal ini disebabkan karena prinsip laboratorium virtual yang tidak menggunakan bahan kimia secara langsung, tetapi hanya melalui aplikasi.

Penggunaan laboratorium virtual dapat meningkatkan hasil belajar siswa, hal ini telah dibuktikan sebelumnya oleh $\mathrm{E}$ Anisah, S Mantini RS, dan T Subroto pada tahun 2013, yakni "Keefektifan Virtual Laboratory terhadap Hasil Belajar Siswa materi Larutan Penyangga dan Hidolisis". Pada penelitian tersebut diperoleh bahwa kelas eksperimen yang menggunakan virtual memiliki rata-rata hasil belajar yang lebih tinggi yakni 80,55 dari pada kelas kontrol sebesar 76,82 [14]. Berdasarkan latar belakang diatas, maka peneliti tertarik untuk mengadakan penelitian dengan judul "Pengaruh Penerapan Metode Pembelajaran Student Teams Achievement Division (STAD) dengan Menggunakan Laboratorium Virtual terhadap Hasil Belajar Siswa pada Mata Pelajaran Kimia di SMA Negeri 1 Mandau Kecamatan Mandau Kabupaten Bengkalis".

Rumusan masalah dari peneliian ini adalah apakah ada pengaruh penerapan metode STAD dengan menggunakan laboratorium virtual terhadap hasil belajar siswa pada mata pelajaran kimia di SMA Negeri 1 Mandau Kecamatan Mandau Kabupaten Bengkalis. Tujuan penelitian ini adalah untuk mengetahui ada atau tidaknya pengaruh penerapan metode Student Teams Achievement Division (STAD) dengan menggunakan Laboratorium Virtual terhadap hasil belajar siswa pada mata pelajaran kimia di SMA Negeri 1 Mandau Kecamatan Mandau Kabupaten Bengkalis.

\section{METODE PENELITIAN}

Penelitian ini adalah quasi experiment. Populasi dalam penelitian ini adalah seluruh siswa kelas X semester II SMA Negeri 1 Mandau Kecamatan Mandau Kabupaten Bengkalis tahun pelajaran 2015/2016. Sampel dalam penelitian ini diambil dengan teknik cluster random sampling, yakni kelas X.3 sebagai kelas eksperimen dan kelas X.4 sebagai kelas control. Rancangan penelitian yang digunakan dalam penelitian ini adalah Pretest-Posttest Control Group Design, yaitu dengan melihat perbedaan pretest maupun posttest antara kelompok eksperimen dan kontrol. Variabel bebas dalam penelitian ini adalah penerapan metode STAD dengan menggunakan laboratorium virtual, sedangkan variabel terikatnya adalah hasil belajar siswa.

Data penelitian diambil dengan berbagai metode, yaitu tes, observasi, dan dokumentasi. Tes digunakan untuk memperoleh data tentang hasil belajar siswa materi pokok reaksi redoks. Tes yang digunakan dalam pengambilan data 
terlebih dahulu diujicobakan. Setelah perangkat tes diujicobakan di kelas XI IPA 3 , langkah selanjutnya adalah menganalisis hasil uji coba soal tersebut. Soal yang telah dianalisis tingkat kesukaran soalnya, daya beda soalnya, reliabilitas, dan dinyatakan valid yang diberikan sebagai soal pretest dan posttest pada kedua kelas sampel. Observasi ini dilakukan untuk memperoleh data tentang proses pembelajaran pada saat penelitian berlangsung, baik aktivitas guru maupun siswa. Lembar observasi ini diisi oleh observer saat penelitian berlangsung. Dokumentasi digunakan untuk memperoleh data nama siswa yang akan dijadikan sebagai sampel. Analisis data akhir meliputi uji homogenitas, uji normalitas, dan uji hipotesis.

\section{HASIL DAN PEMBAHASAN}

Jenis penelitian ini adalah quasi eksperimen yang merupakan pengembangan dari penelitian true eksperimen. Quasi eksperimen ini dipilih karena tidak semua variabel luar terkontrol yang dapat mempengaruhi hasil belajar kimia siswa. Sedangkan desain penelitian yang digunakan adalah Pretest-Posttest Control Group Design. Desain ini membutuhkan dua kelas yang memiliki tingkat kemampuan sama dan masingmasing kelas diberikan pretest dan posttest serta perlakuan yang berbeda.

Maka, untuk mendapat dua kelas yang memiliki kemampuan yang sama tersebut harus dilakukan terlebih dahulu uji homogenitas. Uji homogenitas ini dilakukan menggunakan 20 soal obyektif larutan elektrolit dan non elektrolit yang merupakan materi yang telah dipelajari sebelumnya oleh siswa. Uji homogenitas ini dilakukan pada empat kelas yakni, X.1, X.2, X.3, dan X.4.

Setelah diujikan, jawabannya dianalisis dengan uji Bartlet. Hasil analisis menunjukkan kelas X.1, X.2, X.3, dan X.4 adalah homogen, yakni $X_{\text {hitung }} 3,47<X_{\text {tabel }}$ 7,81. Karena varians-varians homogen maka dapat disimpulkan bahwa keempat kelas tersebut memiliki kemampuan yang homogen dan dapat dijadikan sampel penelitian. Sehingga dalam pengambilan sampel menggunakan teknik cluster random sampling dapat dipilih kelas X.3 sebagai kelas eksperimen dan kelas X.4 sebagai kelas kontrol.

Tabel 1. Rangkuman Analisis Uji Normalitas Data

\begin{tabular}{cccc}
\multicolumn{4}{c}{ Normalitas Data } \\
\hline Kelas & $\chi^{2}{ }_{\text {hitung }}$ & $\chi^{2}$ tabel & Kriteria \\
\hline $\begin{array}{c}\text { Eksperi } \\
\text {-men } \\
\text { Kontrol }\end{array}$ & 10,148 & 11,07 & Normal \\
& & & \\
\hline
\end{tabular}

Tabel 2. Rangkuman Analisis Uji

\begin{tabular}{ccccc}
\multicolumn{5}{c}{ Homogenitas } \\
\hline Kelas & N & Varians & $\begin{array}{c}\mathbf{F} \\
\text { hitung }\end{array}$ & $\begin{array}{c}\mathbf{F} \\
\text { tabel }\end{array}$ \\
\hline $\begin{array}{c}\text { Eksperi } \\
\text {-men } \\
\text { Kontrol }\end{array}$ & 34 & 203,38 & - & - \\
\hline
\end{tabular}

Sebelum dianalisis data pretest dan posttest, terdapat dua syarat yang harus terpenuhi terlebih dahulu, yakni uji normalitas dan uji homogenitas. Setelah dilakukan kedua uji tersebut, diperoleh bahwa data berdistribusi normal dan varians data adalah homogen yang telah tersaji pada Tabel 1 dan Tabel 2. Oleh karena itu, rumus hipotesis yang tepat untuk digunakan adalah uji t. Hal yang perlu diperhatikan selanjutnya adalah banyaknya anggota sampel pada penelitian ini, karena uji t terdiri dari dua rumus, yakni separated varians dan polled varians. Dengan pertimbangan jumlah anggota sampel kelas kontrol dan eksperimen yang tidak sama, maka uji $t$ yang digunakan pada penelitian ini adalah uji $\mathrm{t}$ polled varians. Rumus ini juga memperhatikan selisih antara nilai yang diperoleh siswa pada saat mendapatkan pretest dan posttest. 


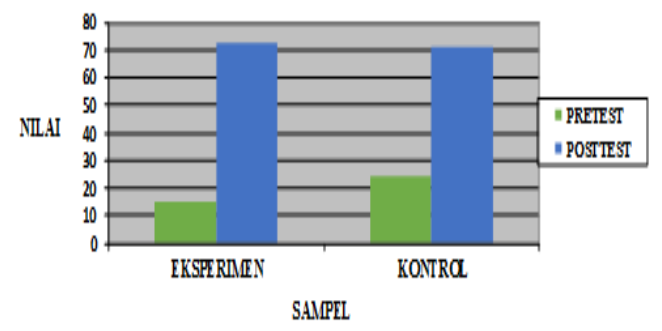

Gambar 1. Diagram Nilai Rata-rata Pretest dan Posttest Kelas Eksperimen dan Kontrol

Adanya pretest terhadap siswa pada kelas eksperimen dan kontrol dapat mengetahui sejauh mana siswa memiliki pengetahuan mengenai materi yang akan diajarkan, yakni reaksi redoks. Berdasarkan hasil pretest yang telah disajikan dalam gambar tersebut, diperoleh informasi bahwa nilai rata-rata pretest baik pada kelas eksperimen atau kelas kontrol masih rendah, yakni nilai rata-rata masingmasingnya tidak mencapai 25 . Hal ini berarti pada kelas eksperimen dan kelas kontrol, masing-masing siswanya hanya memiliki pengetahuan yang sedikit mengenai materi pelajaran yang akan dipelajari.

Rata-rata siswa kelas eksperimen dan kontrol hanya memiliki pengetahuan kurang dari $25 \%$. Hal ini disebabkan karena siswa kebanyakan belum membaca buku pelajarannya mengenai materi selanjutnya di rumah. Walaupun hanya sedikit pengetahuan yang dimiliki siswa berdasarkan pretest, tetapi pengetahuan yang sedikit itu juga akan membantu dalam proses pembelajaran selanjutnya. Sedikit pengetahuan yang telah ada pada siswa akan memudahkan siswa dalam memahami pelajaran selanjutnya yang akan dibahas bersama guru.

Pretest telah diujikan pada siswa di masing-masing kelas dan proses pembelajaranpun dimulai dengan perbedaan metode dan media pembelajaran. Metode pembelajaran Student Teams Achievement Division (STAD) dengan laboratorium virtual diterapkan pada kelas eksperimen, sedangkan kelas kontrol hanya diterapkan metode konvensional, yakni tanpa metode STAD dan laboratorium virtual. Materi reaksi redoks diajarkan sebanyak 4 kali pertemuan dengan metode yang berbeda. Indikator pembelajaran pada reaksi redoks telah diajarkan dan disampaikan kepada siswa pada masing-masing kelas, sehingga dilanjutkan dengan melakukan posttest terhadap kedua kelas tersebut agar mengetahui sejauh mana pemahaman siswa terhadap materi reaksi redoks yang telah diajarkan.

Berdasarkan diagram yang ada pada Gambar 1, terlihat bahwa rata-rata posttest antara kedua kelas adalah berbeda. Jika dilihat hanya dari nilai rata-rata posttest, maka nilai rata-rata kelas eksperimen lebih unggul dibandingkan kelas kontrol. Sedikit lebih unggulnya nilai rata-rata kelas eksperimen belum bisa menunjukkan adanya pengaruh penerapan metode STAD dan laboratorium virtual pada kelas eksperimen. Oleh karena itu, perlu dianalisis mengenai selisih nilai posttest dan pretest pada kelas eksperimen dan kontrol.

Nilai posttest dan pretest yang dimiliki masing-masing kelas diselisihkan. Berdasarkan hasil analisis selisish posttest dan pretest, diperoleh bahwa selisih nilai yang dimiliki kelas eksperimen lebih besar dibandingkan selisih nilai kelas kontrol. Adanya selisih nilai yang tinggi artinya banyak nilai posttest siswa yang lebih baik dan meningkat dari pada nilai pretest sebelumnya.

Tabel 3. Rangkuman Analisis Uji Hipotesis

\begin{tabular}{ccc}
\hline t hitung & t tabel & Keterangan \\
\hline $\mathbf{2 , 8 9 0 4}$ & 1,9983 & Ho ditolak \\
\hline
\end{tabular}

Nilai selisih yang diperoleh akan diujikan dengan rumus uji $t$ agar terlihat apakah hipotesis yang diajukan dapat diterima atau tidak. Berdasarkan Tabel 3, Ho ditolak dan Ha diterima. Artinya ada pengaruh penerapan STAD dengan laboratorium virtual terhadap hasil belajar siswa. Besarnya pengaruh yang diperoleh dapat dianalisis dengan menggunakan 
rumus Koefisien Pengaruh (Kp) yakni besarnya adalah $11,70 \%$.

Pengaruh penerapan metode STAD dan laboratorium virtual dapat mengatasi permasalahan hasil belajar siswa khususnya pada kelas X.3 SMA Negeri 1 Mandau. Hal ini tampak dengan adanya perbedaan nilai rata-rata posttest yang dimiliki kelas X.3 sebagai kelas eksperimen lebih tinggi dibandingkan nilai rata-rata posttest kelas kontrol yakni X.4. Lebih tingginya hasil belajar eksperimen karena penggunaan metode STAD dan laboratorium virtual. Kombinasi penggunaan metode STAD dan laboratorium virtual dapat membuat siswa lebih antusias dalam belajar sehingga meningkatkan pemahamannya dan hasil belajarnya.

Hal lain yang menunjukkan bahwa hasil belajar kelas eksperimen lebih baik dari pada kelas kontrol adalah pada perbedaan nilai rata-rata LKS yang diperoleh kelas kontrol dan kelas eksperimen, seperti diagram telah disajikan pada Gambar 2.

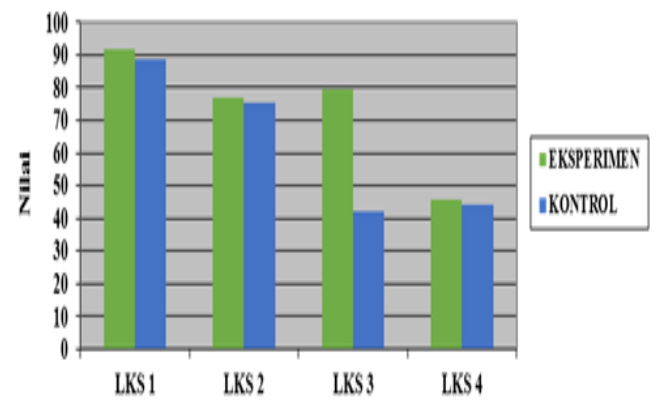

Lembar Kerja Siswa (LKS)

\section{Gambar 2. Diagram Nilai Rata-rata LKS Kelas Eksperimen dan Kontrol}

Berdasarkan diagram yang telah disajikan pada Gambar 2, terlihat bahwa pada saat mengerjakan 4 Lembar Kerja Siswa (LKS) tiap pertemuannya, kelas eksperimen memiliki nilai rata-rata yang lebih tinggi dibandingkan kelas kontrol. LKS diberikan guru dan dikerjakan oleh siswa kelas eksperimen secara diskusi dalam kelompok, sedangkan kelas kontrol siswa mengerjakan secara individu. Siswa kelas eksperimen memiliki nilai rata-rata
LKS lebih unggul, karena penggunaan metode STAD yang membuat siswa aktif berdiskusi dalam kelompoknya untuk memahami materi pelajaran.

Hal yang juga berperan penting dalam unggulnya nilai rata-rata LKS kelas eksperimen ini adalah adanya pembagian anggota tiap kelompok secara heterogen berdasarkan kemampuan akademiknya. Dalam setiap kelompok, terdiri dari beberapa anggota yang berkemampuan tinggi, beberapa kemampuan sedang, dan beberapa lainnya berkemampuan rendah. Oleh karena itu, siswa yang berkemampuan tinggi dalam kelompoknya dapat membantu siswa yang berkemampuan rendah, sehingga nilai ratarata LKS kelas eksperimen dapat lebih unggul. Berbeda pada kelas kontrol, siswa hanya mendapat pengetahuan dari guru dan tidak ada diskusi sesama siswa dalam kelompok, sehingga nilai rata-rata LKS siswa kelas kontrol lebih rendah.

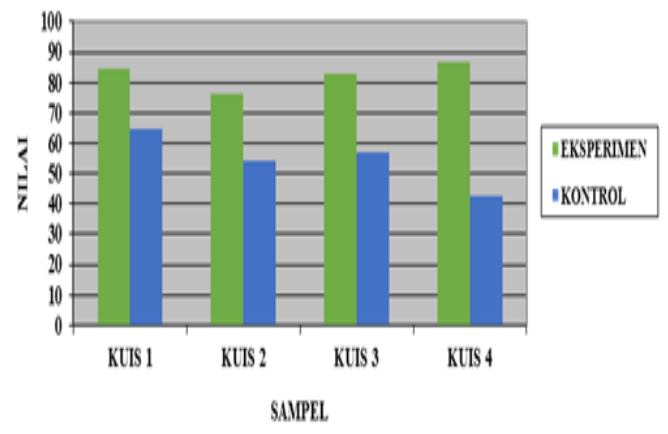

\section{Gambar 3. Diagram Nilai Rata-rata Kuis Kelas Eksperimen dan Kontrol}

Hasil belajar siswa pada aspek kognitif pada penelitian ini, selain dilihat dari nilai posttest dan LKS, dapat juga dilihat dari nilai rata-rata kuis siswa. Hasil rata-rata nilai kuis siswa pada kelas eksperimen dan kontrol telah disajikan pada Gambar 3. Kuis dikerjakan oleh siswa secara individu, baik pada kelas eksperimen ataupun kelas kontrol. Dengan membandingkan nilai rata-rata kuis masing-masing kuis, seperti yang ditunjukkan diagram pada gambar IV.8, diperoleh bahwa nilai kuis tiap pertemuan pada kelas eksperimen juga lebih tinggi dari pada kelas kontrol. 
Nilai kuis kelas eksperimen dapat lebih tinggi karena disebabkan pengaruh penerapan STAD dan laboratorium virtual. Dengan metode ini guru menyampaikan kepada siswa dalam masing-masing kelompoknya untuk mengerjakan kuis dengan sungguh-sungguh karena nilai kuis ini akan diakumulasikan menjadi nilai kelompok. Dimana setiap kelompok yang memiliki skor tertinggi akan mendapatkan penghargaan. Penghargaan ini menyebabkan semangat belajar siswa meningkat, sehingga kuis dapat dikerjakan dengan hasil yang memuaskan.

Penerapan metode STAD dan laboratorium virtual dapat memudahkan siswa memahami materi pelajaran. Penggunaan laboratorium virtual memberikan pengalaman baru bagi siswa untuk melakukan praktikum tanpa berada pada ruang laboratorium asli. Pengalaman siswa melakukan praktikum ini dapat mempermudah pemahaman siswa mengenai terjadinya reaksi redoks. Pada pertemuan pertama, pada kelas eksperimen guru tidak hanya menjelaskan mengenai materi pelajaran tetapi guru juga mengenalkan kepada siswa laboratorium virtual tersebut. Hal ini dilakukan agar siswa mengenal terlebih dahulu aplikasi ini, sehingga pada pertemuan selanjutnya siswa akan lebih paham dan mengerti cara penggunaan aplikasi ini.

Selain itu, laboratorium virtual ini dapat menutupi kekurangan metode STAD. Adapun kekurangan metode STAD tersebut adalah dalam kelompoknya terdapat siswa yang beranggapan tugas akan selesai dikerjakan oleh temannya sehingga siswa tersebut kurang aktif. Namun, adanya penambahan laboratorium virtual ini membuat siswa aktif dalam kelompoknya, karena merupakan pengalaman baru yang dirasakan siswa.

Mudahnya siswa memahami pelajaran di kelas eksperimen juga disebabkan karena STAD merupakan metode yang hampir mirip dengan metode konvensional. Perbedaan antara dua metode ini adalah adanya kelompok dan nilai kuis yang diakumulasikan sehingga akan ada kelompok yang mendapat penghargaan. Persamaan kedua metode ini adalah adanya penyampaian materi yang secara langsung disampaikan oleh guru. Adanya kesamaan metode STAD dengan metode konvensional inilah yang membuat siswa menjadi tidak bingung, sehingga mudah mengikuti proses pembelajaran.

Selain itu, penggunaan laboratorium virtual juga dapat mengatasi permasalahan kelengkapan laboratorium di SMA Negeri 1 Mandau, sehingga siswa dapat melakukan praktikum pada materi reaksi redoks. Laboratorium yang dimiliki SMA Negeri 1 Mandau memiliki keterbatasan ketersediaan alat dan bahan, sehingga adanya laboratorium virtual siswa kelas X.3 dapat juga melakukan praktikum tanpa berada di ruang laboratorium asli. Dalam segi biaya, tidak membutuhkan banyak pengeluaran sekolah untuk biaya pembelian alat ataupun bahan kimia yang harganya mahal. Selain itu, juga mengurangi terjadinya resiko kecelakaan di laboratorium karena hanya menggunakan program aplikasi komputer.

\section{SIMPULAN}

Berdasarkan data akhir diperoleh nilai $\mathrm{t}$ hitung 2,8904 dan $\mathrm{t}$ tabel 1,9983, sehingga nilai $\mathrm{t}$ hitung $>\mathrm{t}$ tabel maka diputuskan bahwa $\mathrm{H}_{0}$ ditolak dan $\mathrm{H}_{a}$ diterima. Hipotesis "Ada pengaruh penerapan metode Student Teams Achievement Division (STAD) dengan menggunakan laboratorium virtual terhadap hasil belajar siswa pada mata pelajaran Kimia di SMA Negeri 1 Mandau Kabupaten Bengkalis" dapat diterima dengan besarnya pengaruh penerapan metode STAD dengan laboratorium virtual terhadap hasil belajar menggunakan rumus Kp sebesar $11,70 \%$.

\section{REFERENSI}

[1] Syaikh Abdurrahman bin Nashir asSa'di, "Tafsir Al-Quran Jilid 3 Surat Al-A'rad, Al-Anfal, at-Taubah, Yunus, Hud, Yusuf", Jakarta: Darul Haq, 2014, h. $387-388$. 
[2] Naba Hamida, Bakti Mulyani, dan Budi Utami, "Studi Komparasi Penggunaan Laboratorium Virtual dan Laboratorium Riil dalam Pembelajaran Student Team Achievement Division (STAD) terhadap Prestasi Belajar ditinjau dari Kreativitas Siswa pada Materi Pokok Sistem Koloid Kelas XI Semester Genap SMA Negeri 1 Banyudono Tahun Pelajaran 2011/2012", Jurnal Pendidikan Kimia (JPK) Program Studi Pendidikan Kimia Universitas Sebelas Maret, Vol. 2, No.2, h.7, 2013.

[3] Galuh Rahardiana, Tri Redjeki, dan Sri Mulyani, "Pengaruh Pembelajaran Contextual Teaching and Learning (CTL) dilengkapi Lab Riil dan Virtuil Terhadap Aktivitas dan Prestasi Belajar Siswa pada Materi Pokok Sistem Koloid Kelas XI IPA Semester Genap SMA Negeri 1 Pulokulon Tahun Pelajaran 2013/2014", Jurnal Pendidikan Kimia (JPK) Program Studi Pendidikan Kimia Universitas Sebelas Maret, Vol. 4, No.1, h. 120, 2015.

[4] Adila Candra Kusumaningrum, dan Sukarmin, "Pengembangan Multimedia Chemtutor pada Materi Reaksi Redoks SMA Kelas XII", UNESA Journal of Chemical Education, Vol. 3, No. 02, h. 75, 2014.

[5] E. Mulyasa, "Kurikulum Tingkat Satuan Pendidikan Sebuah Panduan Praktis", Bandung : PT. Remaja Rosdakarya Offset, 2010, h. 22.

[6] Galuh Rahardiana, Tri Redjeki, dan Sri Mulyani, Loc. Cit., h.120.

[7] Ibid., h.120.

[8] Naba Hamida, Bakti Mulyani, dan Budi Utami, Op. Cit., h. 8.
[9] Aldila Candra Kusumaningrum dan Sukarmin. Op. Cit., h.76.

[10] Ibid., h.76.

[11] Fuad Fitriyanto, Sri Nurhayati, dan Saptorini, "Penerapan Model Pembelajaran Problem Solving pada Materi Larutan Penyangga dan Hidrolisis", Chemistry in Education Universitas Negeri Semarang, Vol. 1, No. 1, h. 41, 2012.

[12] Syaiful Sagala, "Manajemen Strategik dalam Peningkatan Mutu Pendidikan", Bandung : Alfabeta., 2013, h. 37.

[13] Miftahul Huda, "Model-model Pengajaran dan Pembelajaran", Yogyakarta : Pustaka Pelajar, 2013, h. 201.

[14] E Anisah, S Mantini RS, dan T Subroto, "Keefektifan Virtual Laboratory Terhadap Hasil Belajar Siswa Materi Larutan Penyangga dan Hidrolisis", Chemistry in Education Universitas Negeri Semarang, Vol. 2, No. 1, h. 1, 2013. 